S. Baumgartner ${ }^{1}$, A. Holy ${ }^{1}$, R. Schnitzer ${ }^{1}$, M. Schuler ${ }^{2}$, A. Saric ${ }^{2}, N$. Enzinger ${ }^{2}$

\title{
PROPERTIES OF A CREEP RESISTANT 9Cr-1.5Mo-1CO CAST STEEL JOINT WELDED WITH A MATCHING FLUX-CORED WIRE
}

\section{OSOBINE ZAVARENOG SPOJA ČELIČNOG LIVA OTPORNOG NA PUZANJE 9Cr-1.5Mo-1Co SRODNOM PUNJENOM ŽICOM}

\section{Originalni naučni rad / Original scientific paper UDK / UDC: Weld World (2014) 58:565-575 Dol10.1007/s40194-014-0141z}

\section{Rad primljen / Paper received:} Oktobar 2014.

\section{Prevod izvornog rada na srpski jezik: Milica Antić,dipl.ing}

Kljucne riječi: Mehaničke osobine, Odlivci, Materijali otporni na puzanje; Zavareni spojevi, Punjena žica, MAG/MIG zavarivanje

\section{Rezime:}

Godinama je cilj unapređenje efikasnosti termoenergetskih postrojenja, povećanjem temperature pare. Zbog toga su potrebni odgovarajući čelici i potrošni materijali. Poslednji razvoj livenih materijala pokazao je da borom legirani čelik 9Cr-1.5Mo-1Co, nazvan CB2 omogućava temperature pare do $620^{\circ} \mathrm{C}$. S obzirom da punjene žice za zavarivanje $u$ zaštiti gasa nude mnoštvo tehničkih i ekonomskih prednosti, postaju sve popularnije. Iz tih razloga je razvijena srodna punjena žica za proizvodno zavarivanje livenih komponenata. Radi postizanja zahtevanih mehaničkih osobina metala šava, ustanovljena je i odgovarajuća tehnologija zavarivanja. U ovom radu se diskutuje o uticaju parametara zavarivanja na mehaničke osobine nasobnoj temperaturi. Najbolji rezultati se postižu sa najvećim unetim količinama toplote i najmanjim brzinama hlađenja. Dodatno, dati su prvi rezultati ispitivanja puzanja koji pokazuju da su uzorci metala šava i poprečnih preseka spojeva, unutar rasipanja vrednosti za osnovni materijal. MatCalc izračunavanja opisuju mikrostrukturni razvoj u zoni uticaja toplote (ZUT) tokom zavarivanja, termčke obrade posle zavarivanja (TOPZ) i u radu.
Adresa autora / Author's address:

1 S. Baumgartner, A. Holy, R. Schnitzer

voestalpine Böhler Welding Austria GmbH, Böhler-WeldingStraße 1, 8605 Kapfenberg, Austria

e-mail: susanne.baumgartner@voestalpine.com

${ }^{2}$ M. Schuler, A. Saric, N. Enzinger

Institute for Materials Science and Welding, Graz University of Technology, Kopernikusgasse 24, 8010 Graz, Austria

Key words: Mechanical properties, Castings , Creepresisting materials, Welded joints, Cored filler wire, GMAwelding

\section{Abstract}

For years, it has been the aim to improve the efficiency of thermal power plants by increasing the steam temperature. Therefore, appropriate steels and welding consumables are needed. Latest developments in cast materials have shown that the boron-alloyed $9 \mathrm{Cr}-1.5 \mathrm{Mo}-1 \mathrm{Co}$ steel called CB2 enables steam temperatures up to $620^{\circ} \mathrm{C}$. As fluxcored wires for gas metal arc welding offer several technical and economic advantages, they are getting more and more popular. Therefore, a matching flux-cored wire for production welding of cast components has been developed. To obtain the required mechanical properties in weld metal and heat-affected zone, an appropriate welding technology has been established. This paper deals with the influence of welding parameters on the mechanical properties at ambient temperature. Best results could be obtained with higher heat input and lower cooling rate. Additionally, first results of creep tests arepresented and show that weld metal and cross-weld samples are within the scatter band of the base material. MatCalc calculations describe the microstructural evolution in the heat-affected zone (HAZ) during welding, post weld heat treatment (PWHT) and service. 


\section{Uvod}

U okviru evropskih programa COST, razvijen je modifikovani čelik $9 \mathrm{Cr}-1.5 \mathrm{Mo}-1 \mathrm{Co}$ sa dodatkom bora označen kao "CB2" kao najpovoljniji za varijantu livenja. Osnovni materijal postiže svoje odlične visokotemperaturne osobine usled sastava od 0,1 tež.\% ugljenika u kombinaciji sa 9 tež.\% hroma, 1,5 tež.\% molibdena, i dodatnih legirajućih elemenata kao što su vanadijum, niobijum, azot $\mathrm{i}$ bor. Hemijski sastav je dat u tabeli 1 .

Visoka otpornost na puzanje uzrokovana je karbidima $\mathrm{M}_{23} \mathrm{C}_{6}$ bogatim hromom koji uglavnom nastaju na granicama zrna primarnog asutenita i granicama subzrna, fino dispergovanih karbida niobijuma i vanadijum nitrida tipa MX, koji se isto mogu naći na granicama subzrna [2]. Ova disperzija taloga stabilizuje tempperovanu martenzitnu mikrostrukturu,t.j., ferit i karbide tokom visokotemperaturne eksploatacije i značajno doprinosepovećanju granice puzanja. Dodatak bora $\mathrm{u}$ opsegu od $100 \mathrm{ppm}$ dodatno stabilizuje temperovanu martenzitnu mikrostrukturu posebno $u$ blizini granica zrna primarnog austenita, ali takođe smanjuje ogrubljivanje hromnih karbida stvaranjem $\mathrm{M}_{23}(\mathrm{C}, \mathrm{B})_{6}[3,4]$.

Paralelno sa razvojem osnovnog materijala, počeo je i rad na odgovarajućim srodnim potrošnim materijalima $[5,6]$. Zavarivanje punjenom žicom postaje sve popularnje čak i u energetskoj industriji jer nudi neka poboljšanja kao što je lako rukovanje, povećana produktivnost i manji rizik od nastajanja defekata kao što su poroznost i nedostatakstapanja u poređenju sa drugim postupcima zavarivanja. Zbog toga je razvijena srodna žica na bazi sistema rutilno-bazične troske već raspoloživih $9 \% \mathrm{Cr}$ punjenih žica za zavarivanje P91 i P92. Hemijski sastav metala šava je skoro isti kao i hemijski sastav osnovnog materijala.

\section{Introduction}

Within the European COST programs, a modified 9Cr1.5Mo-1Co steel with boron addition designated as "CB2" evolved as the most promising cast variant. The base material achieves its excellent high temperature properties from 0.1 wt. $\%$ carbon in combination with $9 \mathrm{wt} . \%$ chromium, $1.5 \mathrm{wt} . \%$ molybdenum, and additional alloying elements like vanadium, niobium, nitrogen, and boron. The chemical composition is given in Table 1.

The high creep resistance is caused by chromium-rich $\mathrm{M}_{23} \mathrm{C}_{6}$ carbides, which mainly form at prior austenite grain boundaries and subgrain boundaries, finely dispersed carbides, and vanadium nitrides of the type $M X$, which can also be found aligned on subgrain boundaries [2]. This dispersion of precipitates stabilizes the tempered martensitic microstructure, i.e., ferrite and carbides, during high temperature service and contributes significantly to the improvement of creep strength. Boron in the range of $100 \mathrm{ppm}$ additionally stabilizes the tempered martensitic microstructure especially in the 6 vicinity of prior austenite grain boundaries, but also reduces the coarsening of chromium carbides by forming $\mathrm{M}_{23}(\mathrm{C}, \mathrm{B})_{6}[3,4]$.

Parallel to the base material development, the design 6 of matching welding consumables has been started $[5,6]$. Flux-cored wire welding is getting more and more popular even in power generation industry as it offers some general benefits like easy handling, higher productivity, and a lower risk for defects as porosity and lack of fusion compared to other welding processes. Therefore, based on the rutile/basic slag system of already available $9 \% \mathrm{Cr}$ flux-cored wires for welding P91 and P92, a matching filler wire has been developed. The chemical composition of allweld metal was kept close to the chemical composition of the base material.

\begin{tabular}{|c|c|c|c|c|c|c|c|c|c|}
\hline C & Mn & Cr & Mo & Co & Ni & V & Nb & N & B \\
\hline 0.12 & 0.88 & 9.20 & 1.49 & 0.98 & 0.17 & 0.21 & 0.06 & 0.020 & 0.011 \\
\hline
\end{tabular}

Table 1 Measured chemical composition of the 9Cr-1.5Mo-1Co cast steel Cost CB2 in wt.\% [1] Tabela 1: Izmereni hemijski sastav čeličnog liva 9Cr-1.5Mo-1Co Cost CB2 u tež.\% [1] 


\begin{tabular}{|cc|}
\hline & \\
$\mathrm{R}_{\mathrm{e}}$. [MPa] & 590 \\
\hline $\mathrm{R}_{\mathrm{m}}[\mathrm{MPa}]$ & 740 \\
\hline izduženje. [\%] & 17 \\
\hline žilavost [J] & $>30$ \\
\hline
\end{tabular}

Table 3 Typical mechanical properties of all weld metal at ambient temperature with PWHT $730^{\circ} \mathrm{C} / 24 \mathrm{~h}$

Tabela 3: Tipične mehaničke osobine metala šava na sobnoj temperaturi sa TOPZ $730^{\circ} \mathrm{C} / 24 \mathrm{~h}$

Usled pogoršavajućeg uticaja bora na osetljivost prema vrućim prslinama i udarnoj žilavosti, sadržaj $B$ je redukovan [7]. Tipične vrednosti hemijskog sastava i mehaničkih osobina na sobnoj temperaturi metala šava posle termičke obrade posle zavarivanja (TOPZ) od $730^{\circ} \mathrm{C} / 24 \mathrm{~h}$ i hlađenja na vazduhu, prikazane su u tabelama 2 i 3 , prema proizvodnim podacima Böhler-a za CB 2 Ti-FD [8].

Dilatometrijsko merenje koje simulira termički ciklus zavarivanja sa brzinom zagrevanja od $100 \mathrm{~K} / \mathrm{s}$, vršnom temperaturom od $1.300^{\circ} \mathrm{C}$, i vremenom $t_{8 / 5}$ od $20 \mathrm{~s}$ pokazuje martenzit start temperaturu $\left(\mathrm{M}_{\mathrm{s}}\right)$ oko $400^{\circ} \mathrm{C}$ i martenzit finiš temperaturu $\left(\mathrm{M}_{\mathrm{f}}\right)$ od oko $205^{\circ} \mathrm{C}$. Prelazne temperature $A_{c 1}$ i $A_{c 3}$ merene su prema SEP 1680 [9]. Temperature transformacije pobrojane su u tabeli 4. Pri određivanju pogodnih parametara zavarivanja za kvalifikaciju tehnologije zavarivanja (WPQ), ispitivan je uticaj parametra zavarivanja na mehaničke osobine na sobnoj temperaturi. U prvom koraku, testirano je podešavanje parametara za metal šava a kasnije su korišćena podešavanja koja više nude za srodni spoj slično odgovarajućim uslovima za WPQ.

\section{Uticaj parametara zavarivanja na mikrostrukturu i mehaničke osobine metala šava}

Uzorci metala šava zavareni su prema EN ISO 15792-1. Radi istraživanja uticaja parametara zavarivanja na mehaničke osobine na sobnoj temperaturi metala šava, varirane su brzina dotura žice, brzina zavarivanja, redosled slojeva i međuslojna temperatura. Napon je podešen prema brzini dotura žice. $U$ tabeli 5 je dat pregled korišćenih podešavanja i poprečnih preseka metala šava. Debljina lima je $20 \mathrm{~mm}$, a zaštitni gas je $\mathrm{Ar}+18 \% \mathrm{CO}_{2}$ sa protokom od $16 \mathrm{l} / \mathrm{min}$.

\subsection{Mikrostruktura metala šava}

Sprovedena su detaljna mikroskopska ispitivanja optičkim mikroskopom (LOM) i merenje tvrdoće HV 10 na svim uzorcima u uslovimazavarivanja i posle termičke obrade posle zavarivanja (PWHT).
Due to the detrimental influence of boron on hot cracking susceptibility and impact toughness, the B-content has been reduced [7]. The typical values of chemical composition and mechanical properties at ambient temperature of all-weld metal with a post weld heat treatment (PWHT) of $730^{\circ} \mathrm{C} / 24 \mathrm{~h}$ and air cooling are shown in Tables 2 and 3 , respectively, according to the product data sheet of Böhler CB 2 Ti-FD [8]. Dilatometer measurements simulating a welding ther-mal cycle with an on-heating rate of $100 \mathrm{~K} / \mathrm{s}$, a peak temperature of $1,300^{\circ} \mathrm{C}$, and at time $t_{8 / 5}$ of $20 \mathrm{~s}$ showed a martensite start temperature $\left(\mathrm{M}_{\mathrm{s}}\right)$ of about $400^{\circ} \mathrm{C}$ and a martensite finish temperature $\left(\mathrm{M}_{\mathrm{f}}\right)$ of about $205^{\circ} \mathrm{C}$. The transition temperatures $A_{c 1}$ and $A_{c 3}$ were measured according to SEP 1680 [9]. The transformation temperatures are listed in Table 4. To determine suitable parameters for the welding procedure qualification (WPQ), the influence of welding parameters on mechanical properties at ambient temperature were investigated. In the first step, different parameter settings were tested for all-weld metal, and afterwards, the most promising settings were applied on a matching joint similar to the conditions of the WPQ.

2. Influence of welding parameters on microstructure

All-weld metal samples were welded according to EN ISO 15792-1. To investigate the influence of welding parameters on mechanical properties at ambient temperature of all-weld metal, wire feed rate, welding speed, layer sequence, and interpass temperature have been varied. Voltage was adjusted to the wire feed rate. Table 5 gives an overview on the used settings and cross sections of all-weld metal. The plate thickness was $20 \mathrm{~mm}$, and shielding gas $\mathrm{Ar}+18 \% \mathrm{CO}$ with $16 \mathrm{l} / \mathrm{min}$ was used.

\subsection{Microstructure of all-weld metal}

A detailed light optical microscopy (LOM) examination and hardness HV 10 measurements was performed on all samples in as-welded condition and after post weld heat treatment (PWHT). 
U svim slučajevima, zapažena je beinitno/martenzitna mikrostruktura.

U uzorcima 4 i 5 dominantan je martenzitni deo. Mali udeo $\delta$ ferita pojedinačno je raspoređen $u$ metalu šava ili na liniji stapanja regija metala šava koje se posebno javlja u uzorku 5. Primena tretmana TOPZ rezultuje u temperovanoj beinitno/martenzitnoj mikrostrukturi dekorisanoj sa talozima. Fine trake $\delta$-ferita su bile dekorisane intenzivnim talozima karbida (videti slike. 1, 2, 3, 4 i 5). Tvrdoća u uslovima zavarivanja varira od 409 HV10 u uzorku 1 do 441 HV10 u uzorku 5. TOPZ od $730^{\circ} \mathrm{C} / 24 \mathrm{~h}$ rezultuje u temperovanoj i stoga mekšoj mikrostrukturi sa odgovarajućom tvrdoćom od 221-239 HV10 (videti tabelu 6).

\begin{tabular}{ccccccccccc}
$\mathrm{C}$ & $\mathrm{Si}$ & $\mathrm{Mn}$ & $\mathrm{Cr}$ & $\mathrm{Mo}$ & $\mathrm{Co}$ & $\mathrm{Ni}$ & $\mathrm{V}$ & $\mathrm{Nb}$ & $\mathrm{N}$ & $\mathrm{B}$ \\
\hline 0.12 & 0.2 & 0.9 & 9.0 & 1.5 & 1.0 & 0.2 & 0.2 & 0.03 & 0.02 & 0.006 \\
\hline & \\
\hline
\end{tabular}

\subsection{Mehaničke osobine metala šava na sobnoj temperaturi}

Na slici 6 pokazan je rezultat ispitivanja zatezanjem i ispitivanja udarom na sobnoj temperaturi pet varijanti uzoraka metala šava sa TOPZ od $730^{\circ} \mathrm{C} / 24 \mathrm{~h}$. Zatezne osobine su skoro nezavisne od parametara zavarivanja, ali izduženje i energija udara pokazuju neke razlike.

\subsection{Diskusija rezultata}

Mala brzina dotura žice od $10 \mathrm{~m} / \mathrm{min}$, međuslojna temperatura od $150^{\circ} \mathrm{C}$, koja je ispod $\mathrm{M}_{\mathrm{f}}$ od $205^{\circ} \mathrm{C}$, i mala brzina zavarivanja od $20 \mathrm{~cm} / \mathrm{min}$ (varijanta 1) dovode do velike količine unete toplote od $1.78 \mathrm{~kJ} / \mathrm{mm}$ i male brzine hlađenja sa $t_{8 / 5}=13.7 \mathrm{~s}$.

\subsection{Mechanical properties of all-weld metal at ambient temperature}

Figure 6 shows the results of tensile tests and impact tests at ambient temperature of the five variants of all-weld metal samples with a PWHT of $730^{\circ} \mathrm{C} / 24 \mathrm{~h}$. The tensile properties seem to be nearly independent of welding parameter, but elongation and impact energy show some differences.

\subsection{Discussion of results}

A low wire feed rate of $10 \mathrm{~m} / \mathrm{min}$, an interpass temperature of $150^{\circ} \mathrm{C}$, which is below $\mathrm{M}$ of $205^{\circ} \mathrm{C}$, and a low welding speed of $20 \mathrm{~cm} / \mathrm{min}$ (variant 1) lead to a high heat input of $1.78 \mathrm{~kJ} / \mathrm{mm}$ and a low cooling rate with at $\mathrm{t}_{8 / 5}=13.7 \mathrm{~s}$.

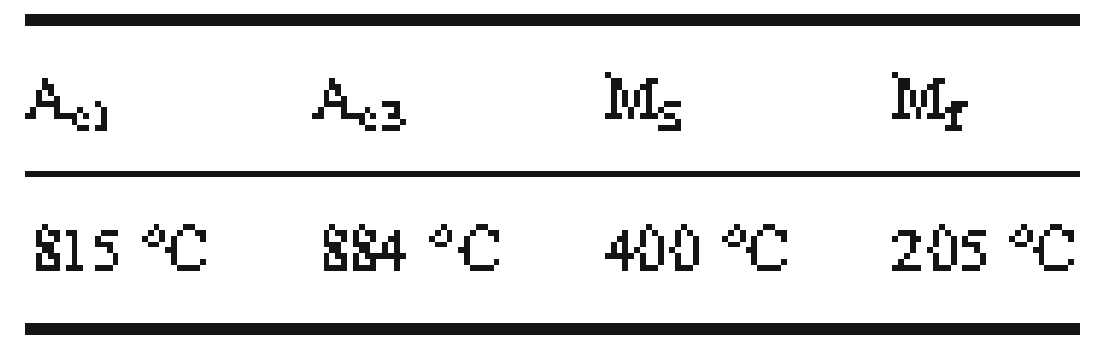

Table 4 Measured transformation temperatures of CB2 weld metal Tabela 4. Izmerene temperature transformacije metala šava CB2 


\begin{tabular}{|c|c|c|c|c|c|}
\hline Varijanta broj & 1 & 2 & 3 & 4 & 5 \\
\hline Poprečni presek & & & & 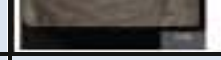 & \\
\hline $\begin{array}{l}\text { Polaganje } \\
\text { slojeva } \\
\text { Slojevi/zavari } \\
\end{array}$ & $\begin{array}{c}6 / 13 \\
\text { Bez njihanja } \\
\end{array}$ & $\begin{array}{c}8 / 17 \\
\text { Bez } \\
\text { njihanja }\end{array}$ & $\begin{array}{c}7 / 14 \\
\text { Bez njihanja }\end{array}$ & $\begin{array}{c}9 / 19 \\
\text { Polunjihanje } \\
\end{array}$ & $\begin{array}{c}6 / 13 \\
\text { Bez njihanja } \\
\end{array}$ \\
\hline \begin{tabular}{|c|}
$\begin{array}{l}\text { Brzina dotura } \\
\text { žice } \\
(\mathrm{m} / \mathrm{min})\end{array}$ \\
\end{tabular} & 10 & 13 & 10 & 10 & 10 \\
\hline Napon (V) & 27 & 29 & 27 & 27 & 27 \\
\hline Jačina struje (A) & 220 & 250 & 230 & 225 & 220 \\
\hline $\begin{array}{l}\text { Međuslojna } \\
\text { temperatura } \\
\left({ }^{0} \mathrm{C}\right)\end{array}$ & 150 & 250 & 250 & 250 & 250 \\
\hline $\begin{array}{l}\text { Brzina } \\
\text { zavarivanja } \\
(\mathrm{cm} / \mathrm{min})\end{array}$ & 20 & 30 & 20 & 30 & 55 \\
\hline $\begin{array}{l}\text { Uneta toplota } \\
(\mathrm{kJ} / \mathrm{mm})\end{array}$ & 1,78 & 1,45 & 1,86 & 1,22 & 0,65 \\
\hline$t_{8 / 5}(s)$ & 13,7 & 12,3 & 12,3 & 10,6 & 7,1 \\
\hline
\end{tabular}

Ove vrednosti su slične sa varijantom 3 samo sa malo većom međuslojnom temperaturom od $250^{\circ} \mathrm{C}$, koja je ispod $\mathrm{M}_{\mathrm{f}}$, gde je uneta toplota blago veća, ali $t_{8 / 5}$ nešto manje
These values are similar to variant 3 , with only higher interpass temperature of $250^{\circ} \mathrm{C}$, which is above Mf, where the heat input was slightly higher, but a little bit lower $t_{8 / 5}$

Table 5 Welding parameters and layer sequence of all-weld metal samples

Tabela 5. Parametri zavarivanja i polaganje slojeva na uzorcima metala šava

as-welded

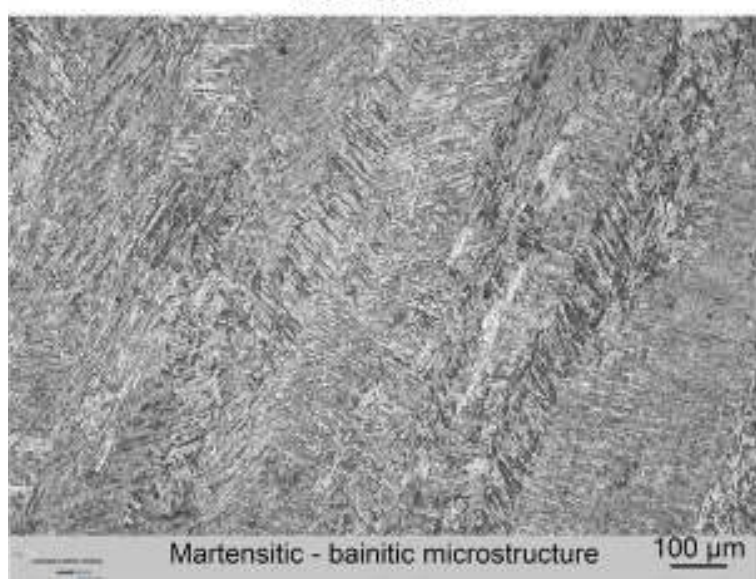

PWHT $730^{\circ} \mathrm{C} / 24 \mathrm{~h}$

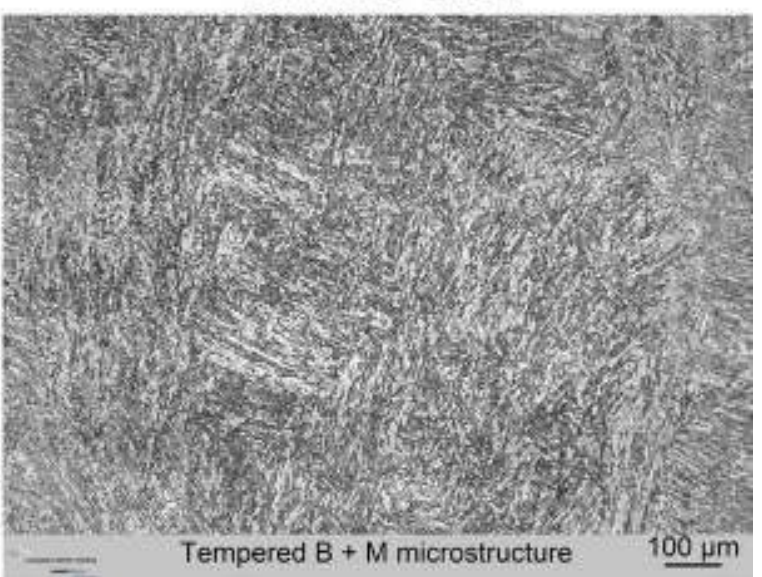

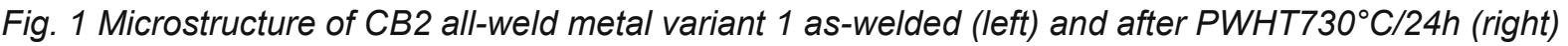
Slika 1 Mikrostruktura metala šava CB2 varijanta 1 zavareno (levo ) i posle $T O P Z 730^{\circ} \mathrm{C} / 24 \mathrm{~h}$ (desno) 

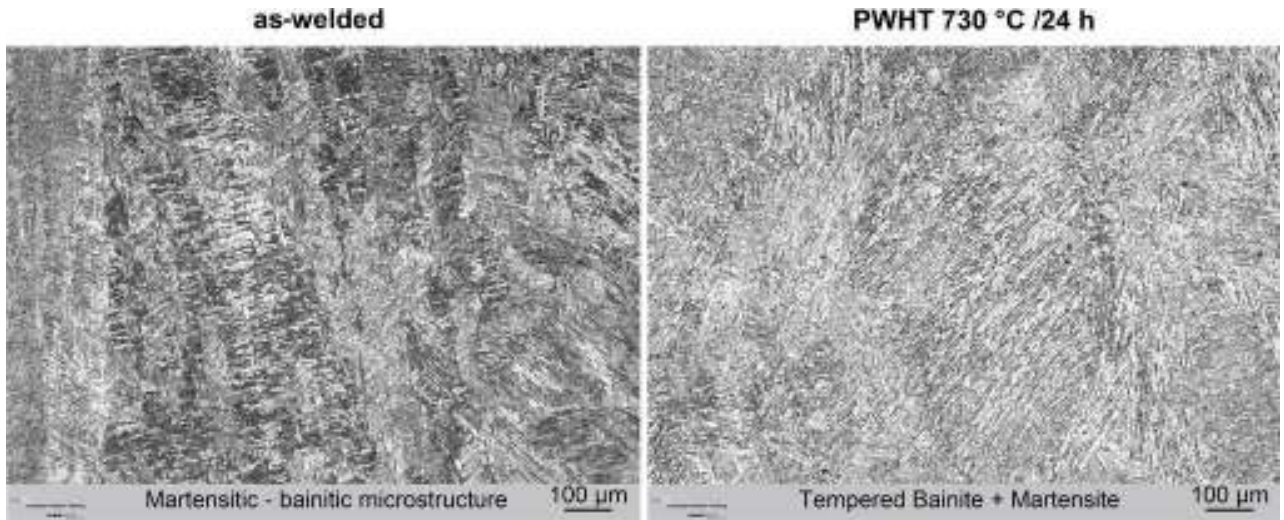

Fig. 2 Microstructure of CB2 all-weld metal variant 2 as-welded (left) and after PWHT730 $\mathrm{C} / 24 \mathrm{~h}$ (right) Slika 2 Mikrostruktura metala šava CB2 varijanta 2 zavareno (levo) i posle TOPZ $730^{\circ} \mathrm{C} / 24 \mathrm{~h}$ (desno)
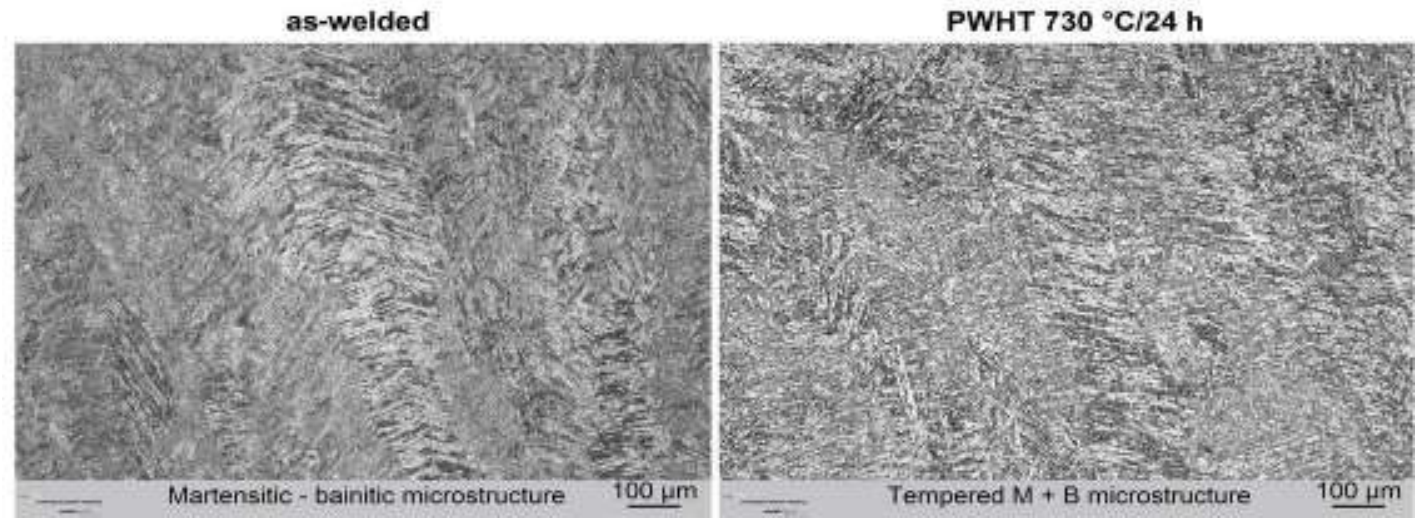

Fig. 3 Microstructure of CB2 all-weld metal variant 3 as-welded (left) and after PWHT730 $\mathrm{P} / 24 \mathrm{~h}$ (right) Slika 3 Mikrostruktura metala šava CB2 varijanta 3 zavareno (levo) i posle TOPZ $730^{\circ} \mathrm{C} / 24 \mathrm{~h}$ (desno)

Varijanta 4 sa većim brzinama zavarivanja od $30 \mathrm{~cm} / \mathrm{min}$ nego kod varijante 3 i polaganjem zavara sa polunjihanjem što daje nešto više tanjih zavara, manju unetu količinu i veću brzinu hlađenja. Kod najvećih brzina zavarivanja od $55 \mathrm{~cm} / \mathrm{min}$ i znatno manjih zavara (varijanta 5), unos toplote je samo $0.65 \mathrm{~kJ} / \mathrm{mm}$ i $t_{8 / 5}=7.1 \mathrm{~s}$, što je skoro polovina $u$ odnosu na varijante $1-3$. U varijanti 2 , primenjena je veća brzina dotura žice od $13 \mathrm{~m} / \mathrm{min}$, što izaziva potrebu za većim naponom i većom jačinom struje. Usled većih brzina zavarivanja od $30 \mathrm{~cm} / \mathrm{min}$, u poređenju sa varijantama 1 i 3 , uneta količina toplote je čak manja i brzina hlađenja je ista kao kod varijante 3 sa istom međuslojnom temperaturom. Mikrostruktura i tvrdoća odgovaraju brzini hlađenja. Veće brzine hlađenja dovode do većeg udela martenzita i manje beinita. Posebno u uslovima zavarivanja, tvrdoća je značajno veća. Sa većim udelom martenzita, žilavost je manja. Mali zavari u varijantama 4 i 5 nemaju dovoljno pozitivan efekat na vrednosti udara. Najbolji rezultati se mogu postići pri većim unetim količinama toplote i manjim brzinama hlađenja. Ovde ne postoji značajan uticaj na zatezne osobine.
Variant 4 with a higher welding speed of $30 \mathrm{~cm} / \mathrm{min}$ than variant 3 and semi-weaving beads lead to slightly more and thinner layers, lower heat input, and higher cooling rate. With the highest welding speed of $55 \mathrm{~cm} / \mathrm{min}$ and much smaller stringer beads (variant 5), the heat input was only $0.65 \mathrm{~kJ} / \mathrm{mm}$ and the $t_{8 / 5}=7.1 \mathrm{~s}$, which is nearly the half of variants $1-3$. In variant 2 , a higher wire feed rate of $13 \mathrm{~m} / \mathrm{min}$ was applied, which afforded higher voltage and lead to higher current. Due to the higher welding speed of $30 \mathrm{~cm} / \mathrm{min}$, compared to variants 1 and 3 , the heat input was even lower and the cooling rate was the same as in variant 3 with the same interpass temperature. Microstructure and hardness corresponded with the cooling rate. Higher cooling rate leads to a higher amount of martensite and less bainite. Especially in as-welded condition, the hardness was significantly higher.

With a higher amount of martensite, the toughness is lower. Small layers in variant 4 and 5 had no sufficient positive effect on impact values. Best results could be obtained with higher heat input and lower cooling rate. There was no significant influence on tensile properties. 

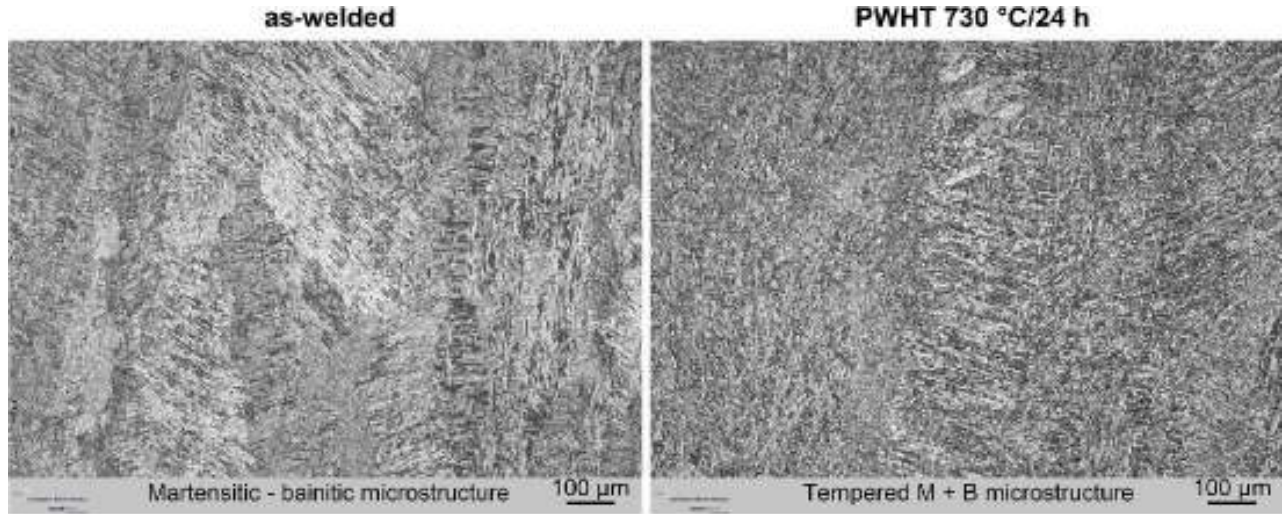

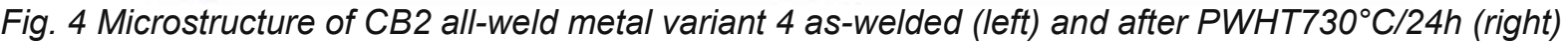
Slika 4 Mikrostruktura metala šava CB2 varijanta 4 zavareno (levo) i posle $\mathrm{TOPZ} 730^{\circ} \mathrm{C} / 24 \mathrm{~h}$ (desno)

as-weldec

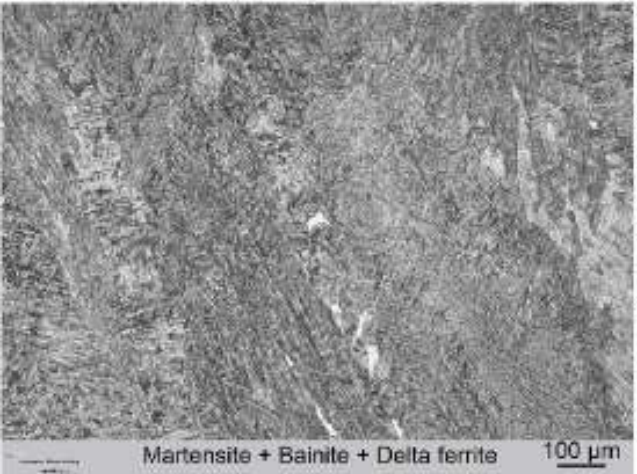

PWHT $730^{\circ} \mathrm{C} / 24 \mathrm{~h}$

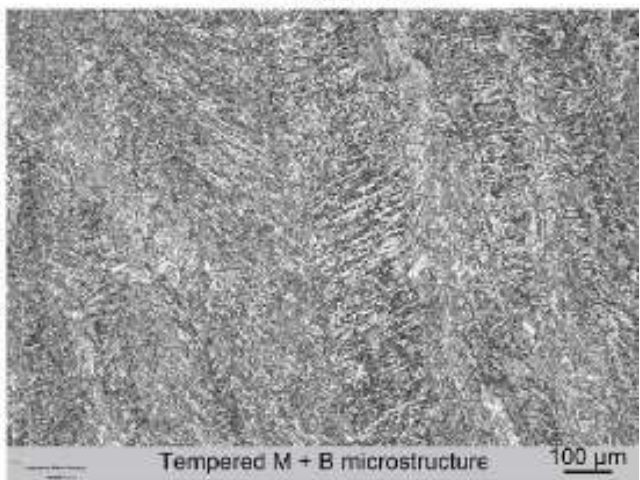

Fig. 5 Microstructure of CB2 all-weld metal variant 5 as-welded (left)andafterPWHT730 ${ }^{\circ} \mathrm{C} / 24 \mathrm{~h}$ (right) Slika 5 Mikrostruktura metala šava CB2 varijanta 1 zavareno (levo) i posle TOPZ $730^{\circ} \mathrm{C} / 24 \mathrm{~h}$ (desno)

\begin{tabular}{cccccc} 
Varijanta broj & 1 & 2 & 3 & 4 & 5 \\
\hline Zavareni uslovi & 409 & 414 & 426 & 412 & 441 \\
${\text { TOPZ } 730^{\circ} \mathrm{C} / 24 \mathrm{~h}}^{221}$ & 229 & 221 & 231 & 239
\end{tabular}

Table 6 Hardness HV10 of CB2 all-weld metals

Tabela 6: Tvrdoća HV10 metala šava materijala CB2

\section{Osobine srodnog spoja}

Zahtevi za WPQ su zatezna čvrstoća od 600MPa i energija udara od 27J [10]. Kako se energija udara smatra kritičnim delom zavarivanja, podešavanje parametara kod varijanti 1 i 2 uzoraka metala šava, je dalo najveće vrednosti energije udara, to je korišćeno kao blisko proizvodno ispitivanje srodnog spoja. Na slici 7 je prikazana priprema šava i polaganje slojeva.

Parametri zavarivanja i poprečni preseci pobrojani su u tabeli 7 .

\subsection{Mikrostruktura metala šava i ZUT bez TOPZ}

Ispitivanje optičkom mikroskopijom i merenje tvrdoće HV10 sprovedena su na uzorcima poprečnog preseka u zavarenim uslovima. Na slici 8 prikazane su mikrostrukture završnog sloja u uslovima zavarivanja. Obe se karakterišu martenzitno/beinitnom mikrostrukturom.

\section{Properties of matching joint}

The requirements for the WPQ are tensile strength of $600 \mathrm{MPa}$ and impact energy of 27J [10]. As impact energy is assumed to be the critical part of the welding, the parameter settings of variant 1 and 2 of all-weld metal samples, which resulted in highest impact energy, were used for near production tests of a matching joint. Figure 7 shows the seam preparation and the layer sequence. Welding parameters and cross sections are listed inTable 7.

\subsection{Microstructure of weld metal and HAZ without PWHT}

Light optical microscopy (LOM) examination and hardness HV10 measurements were performed on crossweld samples in as-welded condition. Figure 8 shows the microstructure of the cap layer in as welded condition. Both are characterized by martensitic/bainitic microstructure. 
Kod varijante II sa višom međuslojnim temperaturom, mikrostruktura je grublja i udeo martenzita je veći. Ovo odgovara nešto većim vrednostima tvrdoće od 406 HV10 (pojedinačne vrednosti 396-416 HV10) u poređenju sa varijantom I sa 394 HV10 (pojedinačne vrednosti 387-403 HV10).

$\mathrm{Na}$ slici 9 prikazana je mikrostruktura zone uticaja toplote (ZUT). Ne postoji značajna vidljiva razlika: grubozrna zona uticaja toplote (GZZUT) karakteriše se beinitno/martenzitnom mikrostrukturom sa malim udelom $\delta$-ferita, finozrna zona uticaja toplote (FZZUT) mikrostrukturom sa manje martenzita $u$ oba slučaja.

\subsection{Mehaničke osobine na sobnoj temperaturi posle TOPZ}

Udarna žlavost metala šava i ZUT ispitivana je posle TOPZ od $730^{\circ} \mathrm{C} / 24 \mathrm{~h}$ na dve pozicije (videti sliku10). Rezultati su dati na sl. 11. Udarna žilavost ZUT je manja nego u metalu šava, ali u svim slučajevima, srednja vrednost prevazilazi zahtevanu vrednost 27J. Profil tvrdoće prikazan je na sl.12. Profil tvrdoće pokazuje ne samo vrh u ZUT blizu linije stapanja već takođe veći ili manji pad tvrdoće koji odgovara najgorem položaju spoja.
In variant II with higher interpass temperature, the microstructure is coarser and the amount of martensit is higher. This corresponds to a slightly higher mean hardness of 406 HV10 (single values 396-416 HV10) compared to variant I with 394 HV10 (single values 387-403 HV10).

Figure 9 shows the microstructure of the heataffected zone (HAZ). There is no significant difference visible: the coarse-grain heat-affected zone (CGHAZ) is characterized by bainitic/martensitic microstructure with a small amount of $\delta$-ferrite, the fine-grain heat-affected zone (FGHAZ) by smaller martensitic microstructure in both cases.

\subsection{Mechanical properties at ambient temperature after PWHT}

Impact toughness of weld metal and HAZ has been tested after PWHT of $730^{\circ} \mathrm{C} / 24 \mathrm{~h}$ on two positions (see Fig. 10). The results are shown in Fig. 11. The impact energy of the HAZ is lower than in the weld metal, but in all cases the average value exceeds the required $27 \mathrm{~J}$. The hardness profile is shown in Fig. 12. The hardness profile shows not only a peak in the HAZ near the fusion line but also a more or less considerable hardness drop, which points out the weakest position of the joint.
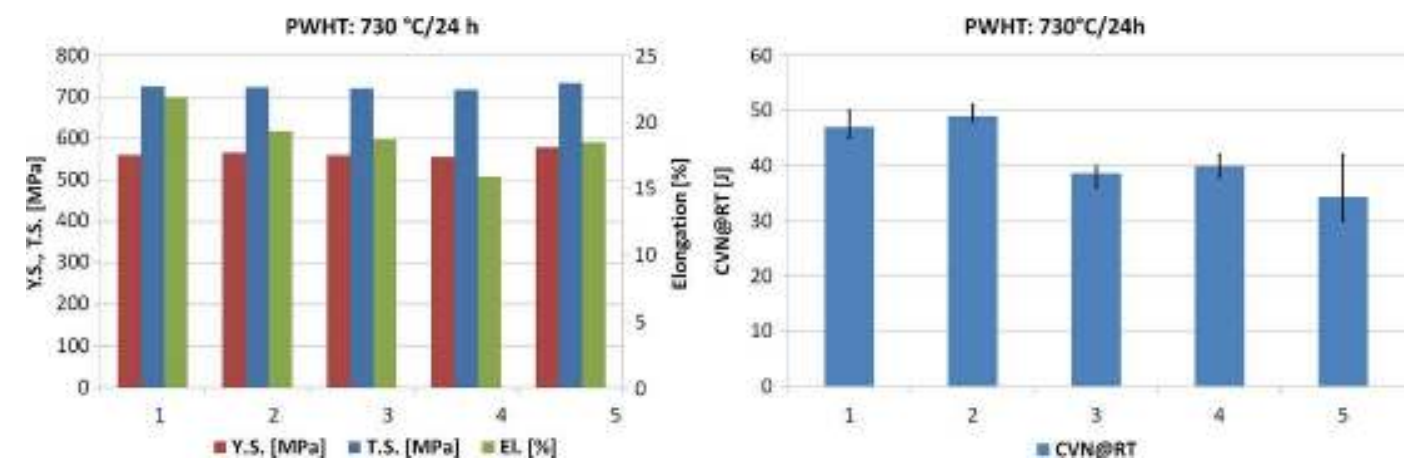

Fig. 6 Mechanical properties of all-weld metal at ambient temperature with PWHT of $730^{\circ} \mathrm{C} / 24 \mathrm{~h}$

Slika 6. Mehaničke osobine metala šava na sobnoj temperaturi sa TOPZ od $730^{\circ} \mathrm{C} / 24 \mathrm{~h}$
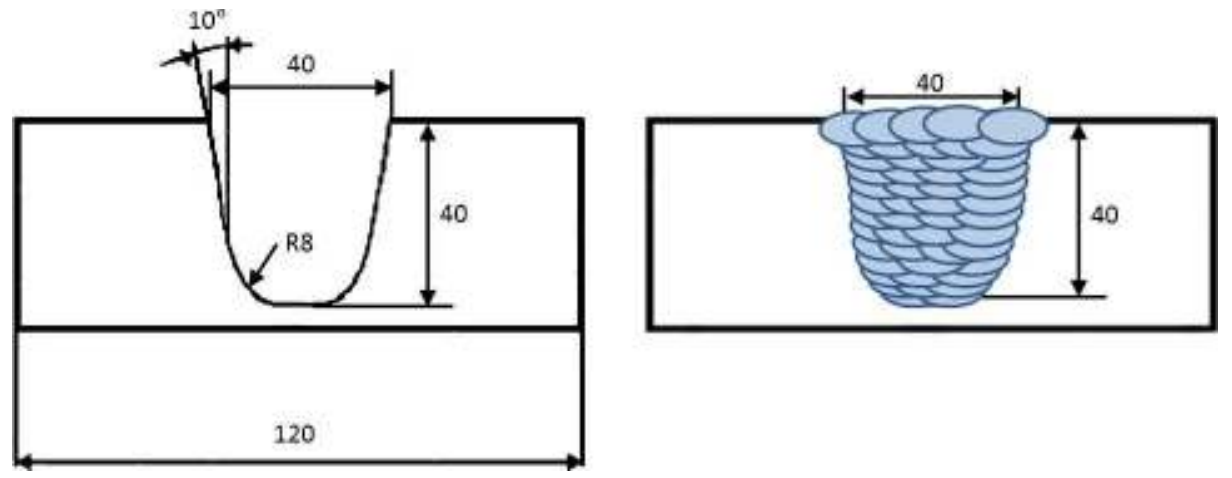

Fig. 7 Joint preparation and layer sequence of CB2 weld

SI.7 Priprema spoja i polaganje zavara u šavu CB2 


\begin{tabular}{l|c|c|}
\hline Variant number & I & II \\
\hline & & \\
\hline
\end{tabular}

Table 7 Welding parameters of CB2 butt weld

Tabela 7: Parametri zavarivanja sučeonog spoja od CB2

\subsection{Diskusija rezultata}

Varijanta I sa međuslojnom temperaturom od $150^{\circ} \mathrm{C}$, brzinom dotura žice od $10 \mathrm{~m} / \mathrm{min}$, i brzinom zavarivanja od $20 \mathrm{~cm} / \mathrm{min}$ ima unetu količinu toplote od $1.82 \mathrm{~kJ} / \mathrm{mm}$ i $t_{8 / 5}=11.8 \mathrm{~s}$. Varijanta II sa međuslojnom temperaturom od $250^{\circ} \mathrm{C}$, većom brzinom dotura od $13 \mathrm{~m} / \mathrm{min}$ i stoga većom jačinom struje i naponom ali većom brzinom zavarivanja od $30 \mathrm{~cm} / \mathrm{min}$ dovodi do manje količine unete toplote od $1.53 \mathrm{~kJ} / \mathrm{mm} \mathrm{i} \mathrm{t}$ 8/5 $=18.7 \mathrm{~s}$.

U oba slučaja se zapažaju vrlo slične beinitno/martenzitne mikrostrukture. Mada je brzina hlađenja kod varijante II manja, udeo martenzita a takođe i vrednost tvrdoće su veći. Dodatno, mikrostruktura je nešto grublja. Ovo odgovara boljim vrednostima udarne žilavosti kod varijante I. U ZUT, nema razlika u mikrostrukturi krakterističnih za objašnjenje bolje vrednosti udarne žilavosti kod varijante I. Zavisno od vrhova i padova vrednosti tvrdoće u ZUT, to znači da je ZUT najkritičnija oblast i za čvrstoću i za žilavost.

\subsection{Discussion of results}

Variant I with interpass temperature of $150^{\circ} \mathrm{C}$, wire feed rate of $10 \mathrm{~m} / \mathrm{min}$, and welding speed of $20 \mathrm{~cm} / \mathrm{min}$ lead to a heat input of $1.82 \mathrm{~kJ} / \mathrm{mm}$ and a $\mathrm{t}_{8 / 5}=11.8 \mathrm{~s}$. Variant II with interpass temperature of $250^{\circ} \mathrm{C}$, higher wire feed rate of $13 \mathrm{~m} / \mathrm{min}$ and therefore higher current and voltage but higher welding speed of $30 \mathrm{~cm} / \mathrm{min}$ lead to lower heat input of $1.53 \mathrm{~kJ} / \mathrm{mm}$ and $\mathrm{t}_{8 / 5}=18.7 \mathrm{~s}$.

In both cases, a very similar bainitic / martensitic microstructure is observed. Although the cooling rate was lower in variant $\mathrm{II}$, the amount of martensite and also the hardness are a little bit higher. Additionally, the microstructure is slightly coarser. This is corresponding to the better impact values of variant I. In the HAZ, no difference in microstructure is characterized to explain the better impact values of variant I. Due to the hardness peak and drop in the HAZ, it seems that the HAZ is the most critical area concerning strength and toughness. 

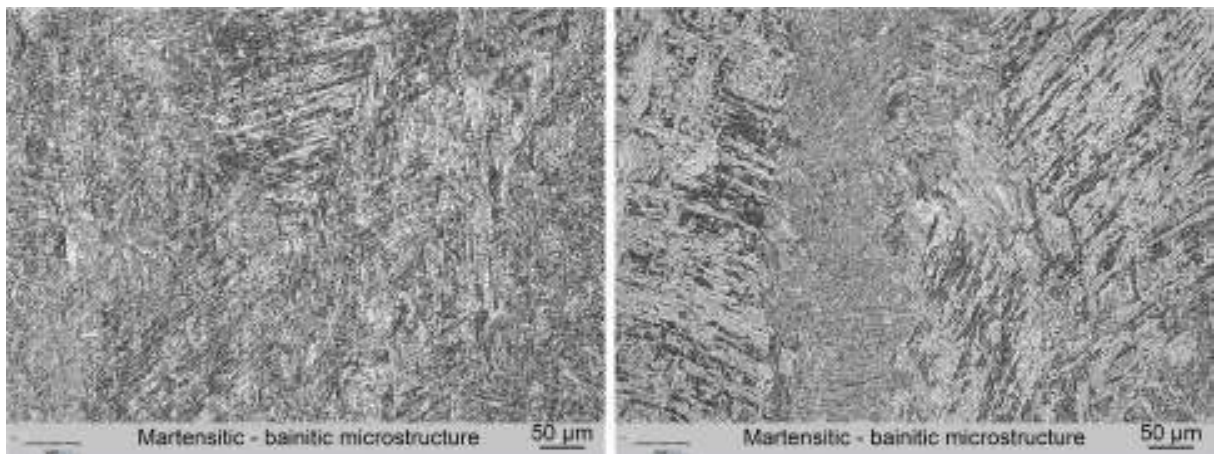

Fig. 8 Microstructure of caplayer in as-welded condition left: variant I, right: variant II SI. 8. Mikrostrktura završnog sloja u uslovima zavarivanja- levo varijanta I, desno, varijanta II
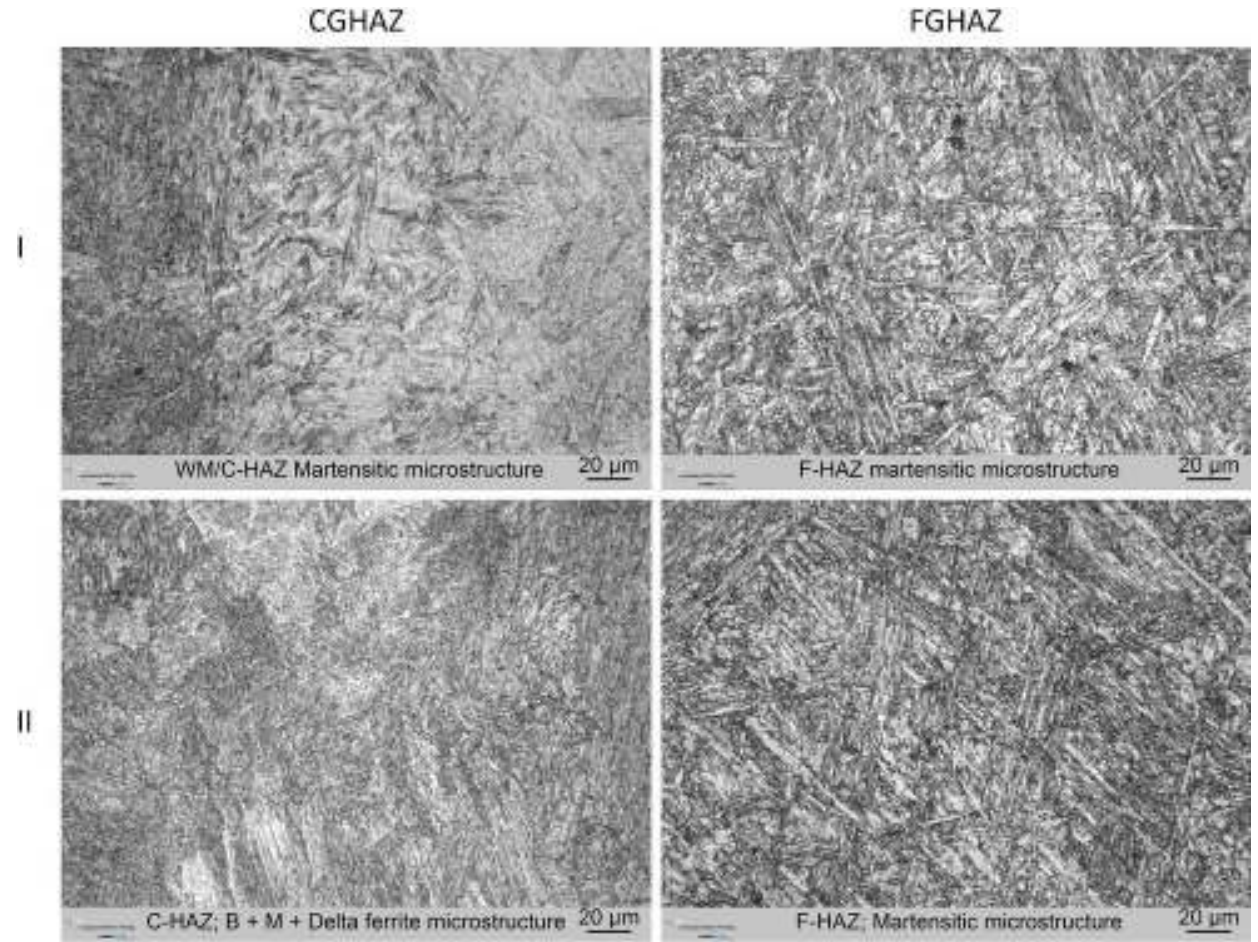

Fig. 9 Microstructure in HAZ of matching CB2 joint

SI. 9. Mkrostruktura u ZUT rodnog spoja CB2

Da bi se detaljnije shvatio uticaj parametara zavarivanja na mehaničke osobine, potrebna su dalja ispitivanja. Ipak, kvalifikacija tehnologije zavarivanja kojom se kvalifikuje punjena žica Böhler CB 2 Ti-FD za korišćenje pri zavarivanju velike skale livenih delova od CB2, zavareni su u voestalpine livnici u Linz i Traisen i uspešno su prošli [10].
To get a more detailed understanding of the influence of welding parameters and mechanical properties, further investigations are necessary. Nevertheless, welding procedure qualifications, which qualify the flux-cored wire Böhler CB 2 Ti-FD to be used for welding of large-scale cast components of CB2, were welded at the voestalpine foundary at Linz and Traisen and passed successfully [10].

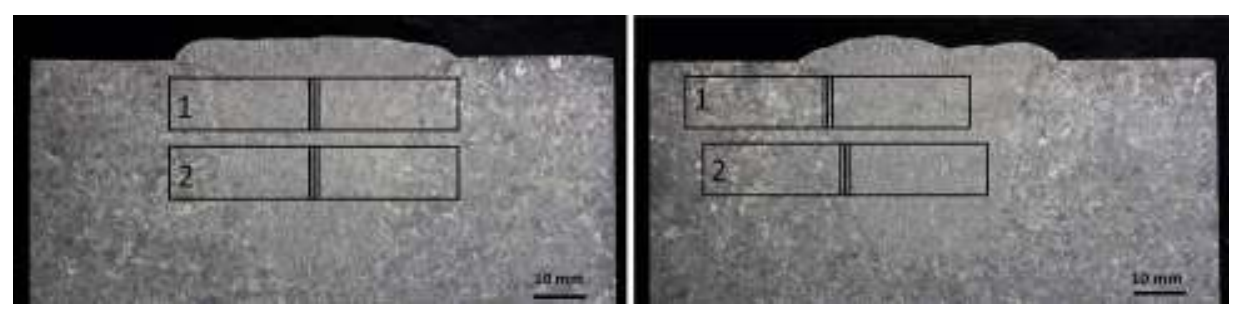

Fig. 10 Position of impact specimens in weld metal (left) and HAZ (right) SI.10. Položaj epruveta za udarnu žilavost u metalu šava (levo) i ZUT (desno) 


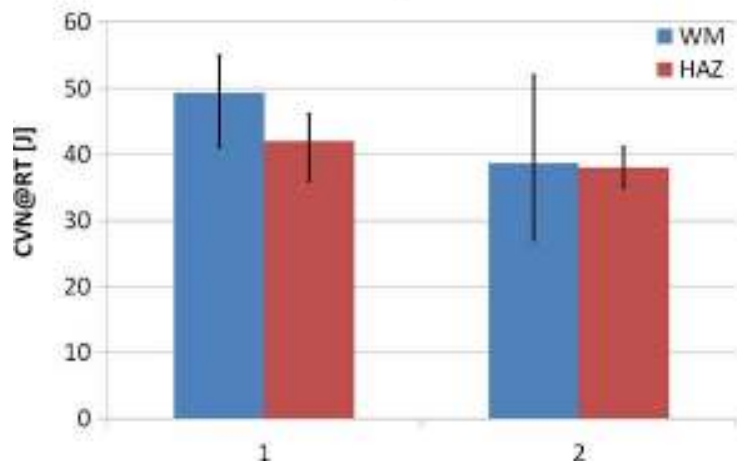

II

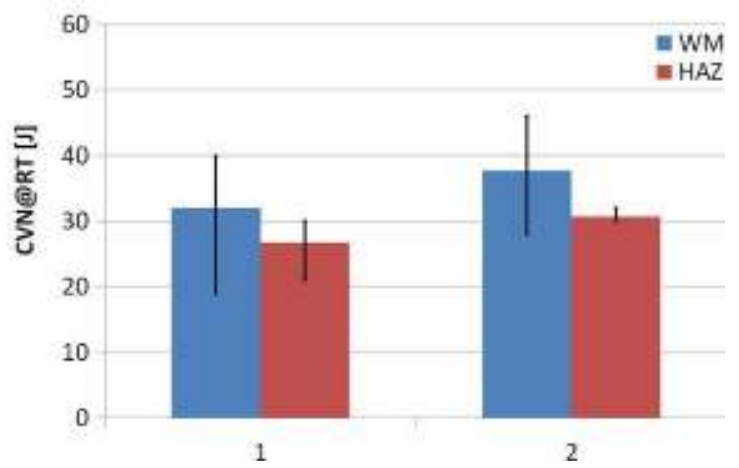

Fig. 11 Impact toughness of weld metal and HAZ of matching CB2 joint SI.11. Udarna žilavost metala šava i ZUT srodnog spoja CB2

।

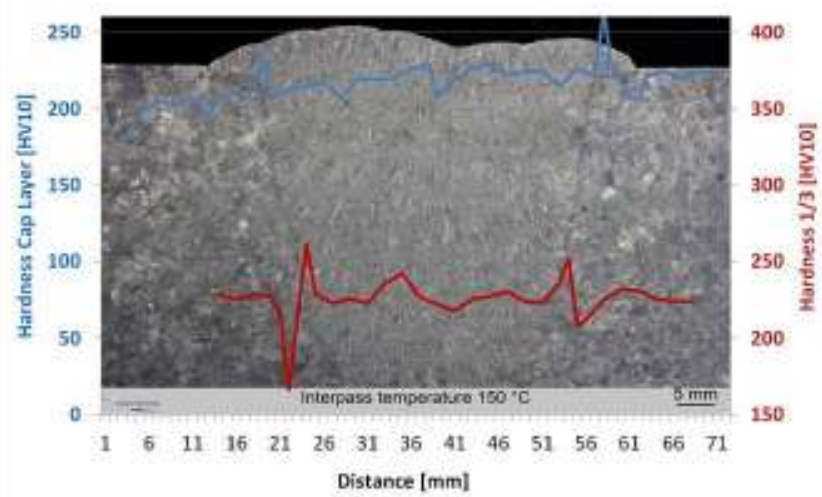

\begin{tabular}{|c|l|l|l|l|}
\hline BM & HAZ & WM & HAZ & \multicolumn{1}{|c|}{ BM } \\
\hline $182-$ & $207-$ & $207-$ & $206-$ & $220-$ \\
207 & 235 & 230 & 263 & 225 \\
\hline $225-$ & $166-$ & $218-$ & $208-$ & $224-$ \\
229 & 261 & $242-$ & 242 & 232 \\
\hline
\end{tabular}

Fig. 12 Hardness profile of matching CB2 joint

SL.12.Profil tvrdoće spoja CB2 (BM-O:M:; HAZ-ZUT, WM-M.Š.)

\section{Ispitivanje granice puzanja}

Ispitivanje granice puzanja izvedeno je na epruvetama iz poprečnog preseka zvarenog spoja i metala šava zavarenih sa parametrima iz varijante II pokazuju vreme trajanja od $6.572 \mathrm{~h}$ na $625^{\circ} \mathrm{C}$ i pokazuje da su granice puzanja metala šava i epruveta poprečnih na zavareni spoj unutar-20\% rasipanja vrednosti u odnosu na osnovni materijal (videti sl. 13). Vreme trajanja epruveta iz metala šava je duže ne kod onih tiz popečnog preseka koje su se lomile u osnovnom materijalu i zoni uticaja toplote (videti sl.14 i 15). Sledila su ispitvanja skenirajućim elektronskim mikroskopom (SEM) i EDX otkrivenih čestica bogatih Mo prečnika oko $1 \mu \mathrm{m}$ (videti sl. 16), koje su okarakterisane kao Lave faza.
II

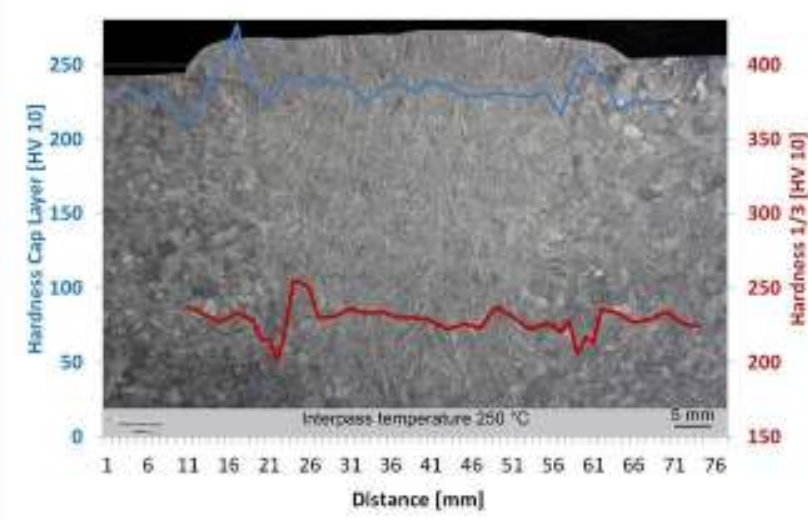

\begin{tabular}{|c|c|c|c|c|}
\hline BM & HAZ & WM & HAZ & BM \\
\hline $222-$ & $213-$ & $216-$ & $234-$ & $219-$ \\
233 & 259 & 243 & 254 & 226 \\
\hline $227-$ & $201-$ & $222-$ & $213-$ & $224-$ \\
237 & 255 & 237 & 228 & 236 \\
\hline
\end{tabular}

\section{Creep rupture tests}

Creep rupture tests of cross-weld and weld metal specimens welded with parameters of variant II show running times up to $6,572 \mathrm{~h}$ at $625^{\circ} \mathrm{C}$ and prove that the creep rupture strength of weld metal and cross-weld specimens are within the $-20 \%$ scatterband of the base material (see Fig. 13). The running times of the weld metal specimens are longer than that of the cross-weld specimens which fractured in base metal and heataffected zone, respectively (see Figs. 14 and 15). Further investigations with scanning electron microscope (SEM) and EDX revealed Mo-rich particles of about $1 \mu \mathrm{m}$ in diameter (see Fig. 16), which have been characterized as Laves phase. 
Za dealjniju karakterizaciju taloga, potrebna su ispitivanja TEM. Prema simulaciji MatCalc stabilni su $\mathrm{M}_{23} \mathrm{C}_{6}$, Lave faza, $\mathrm{Nb}(\mathrm{C}, \mathrm{N})$, i bor nitrid $(\mathrm{BN}) \mathrm{u}$ metalu šava posle TOPZ i ekploatacije [11].
For more detailed characterization of precipitates, TEM investigations are necessary. According to MatCalc simulations, $\mathrm{M}_{23} \mathrm{C}_{6}$, Laves phase, $\mathrm{Nb}(\mathrm{C}$, $\mathrm{N})$, and boron nitride (BN) are stable in weld metal after PWHT and service [11].

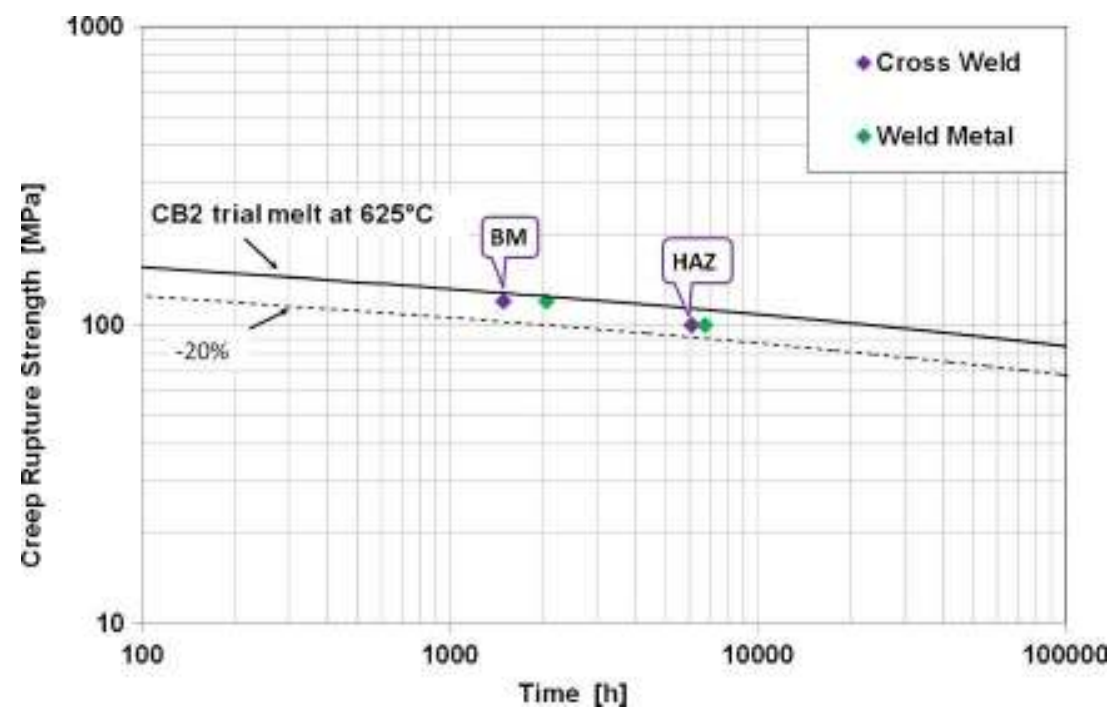

Fig. 13 Creep rupture tests of CB2 cross-weld and weld metal specimens at $625^{\circ} \mathrm{C}$

SI. 13. Ispitivanje granice puzanja CB2 epruveta iz metala šava i poprečnona šav na $625^{\circ} \mathrm{C}$
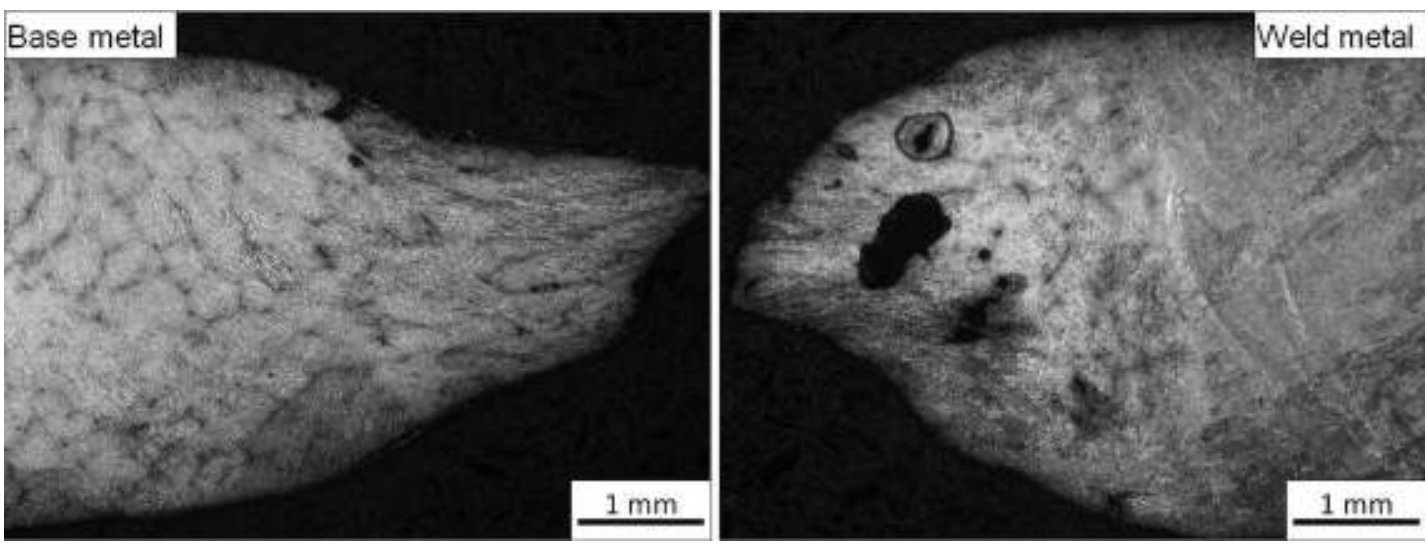

Fig. 14 Fracture location of cross-weld specimen $120 \mathrm{MPa}, 1,492 \mathrm{~h}$

SI. 14. Lokacija loma epruvete poprečno na šav 120Mpa, $1.492 \mathrm{~h}$

\section{Simulacija razvoja mikrostrukture}

Razvoj taloga je jako vezan za hemijski sastavi primenjeni termički ciklus. Uz pomoć termokinetičkog softverskog paketa MatCalc [12, 13] izračunate su fazna frakcija, srednja vrednost radijusa i gustina taloga kao funkcija vremena.

\subsection{Metal šava}

Tokom zavarivanja, $\mathrm{BN}$ i $\mathrm{Nb}(\mathrm{C}, \mathrm{N})$ formiraju jezgra i ostaju stabilni.

Boridi, $\mathrm{M}_{7} \mathrm{C}_{3}$ i cementit nisu stabilni i ponovo se rastvaraju .

\section{Simulation of microstructure evolution}

The evolution of precipitates is strongly influenced by the chemical composition and the applied thermal cycle. With the thermokinetic software package MatCalc [12, 13]phase fraction, mean radius and number density of precipitates were calculated as a function of time.

\subsection{Weld metal}

During welding, $\mathrm{BN}$ and $\mathrm{Nb}(\mathrm{C}, \mathrm{N})$ nucleate and remain stable.

Borides, $\mathrm{M}_{7} \mathrm{C}_{3}$, and cementite are not stable and dissolve 

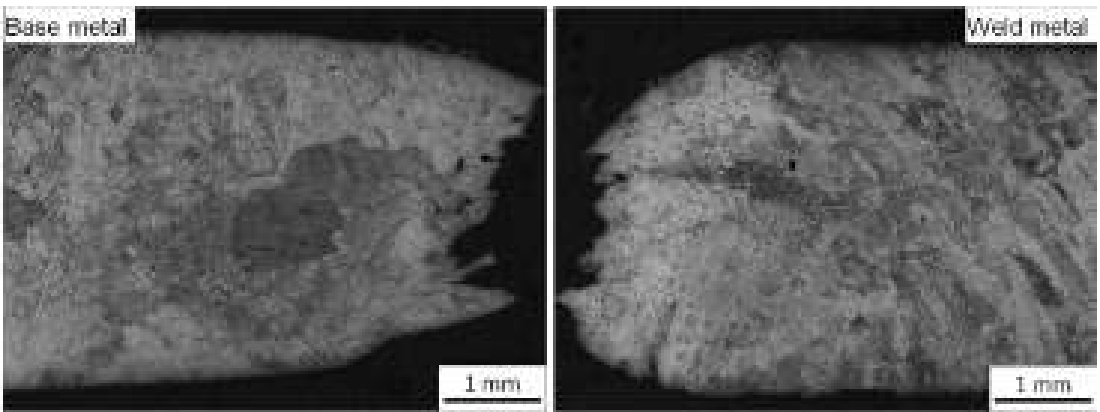

Fig. 15 Fracture location of cross-weld specimen100 MPa, 6,118 h

SI. 15. Lokacija loma na epruveti poprečno na šav 100 Mpa, 6.118 h
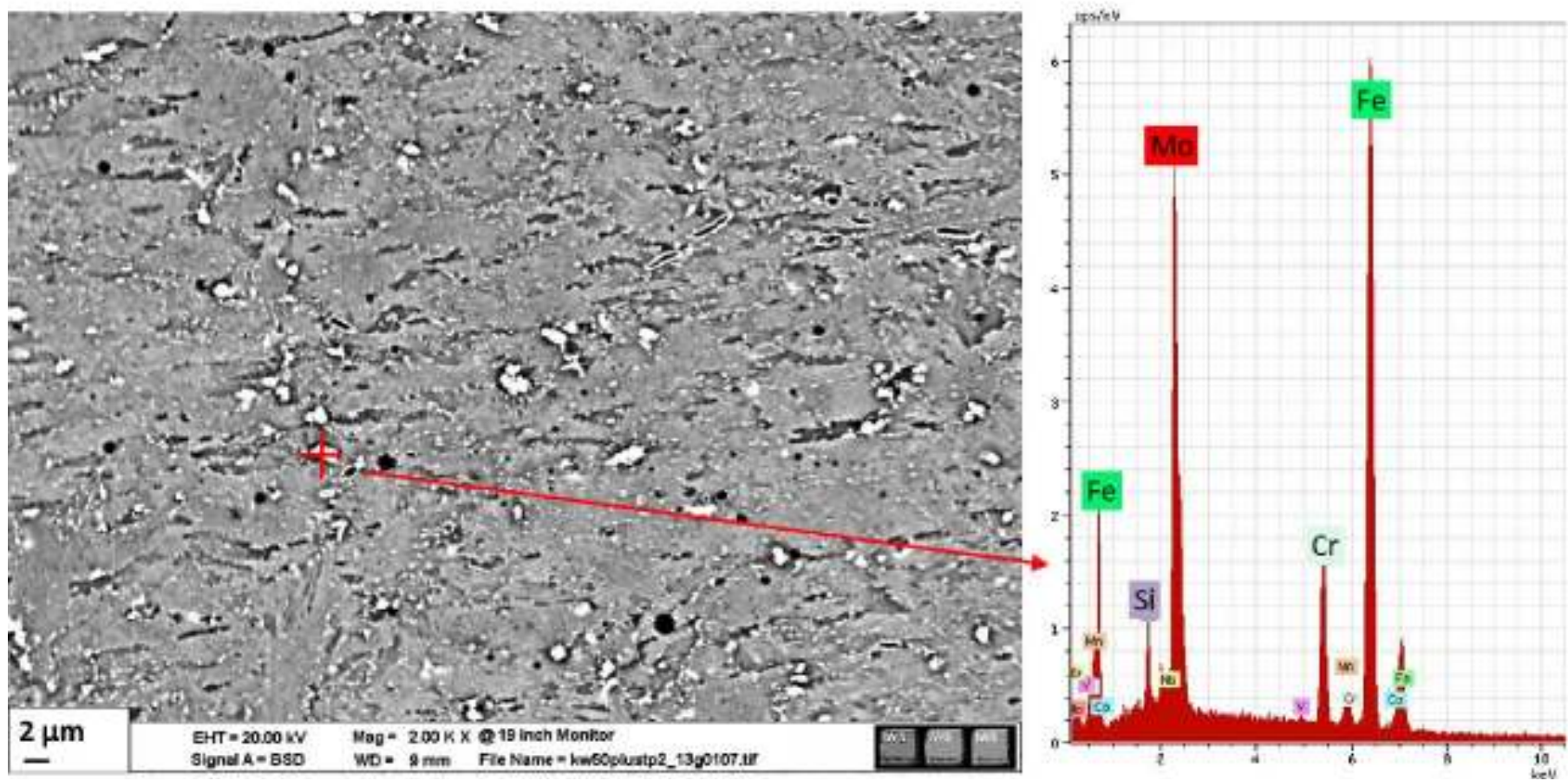

Fig. 16 SEM picture of microstructure of CB2 weld metal sample after $6,572 \mathrm{~h}$ at $625^{\circ} \mathrm{C}$ SI. 16. SEM slika mikrostrukture uzorka metala šava CB" posle $6.572 \mathrm{~h}$ na $625^{\circ} \mathrm{C}$

$\mathrm{M}_{23} \mathrm{C}_{6}$ karbidi se talože tokom TOPZ od $730{ }^{\circ} \mathrm{C} / 24$ h. Posle TOPZ, glavni talog se sastoji od $\mathrm{M}_{23} \mathrm{C}_{6}$, $\mathrm{Nb}(\mathrm{C}, \mathrm{N})$, i BN. Lave faza se javlja posle nekoliko sati eksploatacije na $625^{\circ} \mathrm{C}[11]$.

\subsection{ZUT}

Za proračun razvoja taloga u ZUT, korišćen je hemijski sastav osnovnog materijala prema tabeli1. Posle simulacije livenja i kvalitaetne termičke obrade osnovnog materijala, glavni talozi su $\mathrm{M}_{23} \mathrm{C}_{6}$, $\mathrm{NbC}, \mathrm{BN}$ i vanadijum nitrid ( $\mathrm{VN}$ ).

Za simulaciju višeslojnog zavarivanja, razmatran je temperaturni ciklus sa dve vršne temperature od 1.300 i $1.000^{\circ} \mathrm{C}$, praćeno TOPZ od $730{ }^{\circ} \mathrm{C} / 24 \mathrm{~h}$. Rezultati simulacije tokom zavarivanja, TOPZ i servisa su prikazani su na sl. 17. Prva kolona pokazuje ciklus temperatura-vreme, druga kolona
M23C carbides precipitate during PWHT of 730 ${ }^{\circ} \mathrm{C} / 24$ h. After PWHT, M6C6 , Nb(C, N), and BN are the main precipitates. Laves phase occurs after few hours of service at $625^{\circ} \mathrm{C}$ [11].

\subsection{HAZ}

For calculating the evolution of precipitates in the $\mathrm{HAZ}$, the chemical composition of the base material according to Table 1 was used. After simulation of casting and quality heat treatment of the base material, the main precipitates are $\mathrm{M}, \mathrm{NbC}, \mathrm{BN}$, and vanadium nitride (VN). To simulate a multilayer welding, a temperature cycle with two peak temperatures of 1,300 and $1,000^{\circ} \mathrm{C}$, respectively, was considered, followed by PWHT of $730^{\circ} \mathrm{C} / 24 \mathrm{~h}$. The results of simulation during welding, PWHT, and service are presented in Fig. 17. The first row 
shows the temperature-time cycle, the second row pokazuje udeo faze u tež.. \%, treća kolona pokazuje srednje vrednosti radijusa u nanometrima i zadnja kolona pokazuje gustinu taloga u delovima po kubnom metru. Tokom zavarivanja i TOPZ, javljaju se neke promene, ali na kraju su talozi slični prethodnom statusu.

Samo udeo faze VN je nešto veći, a udeo $\mathrm{NbC}$ blago manji.
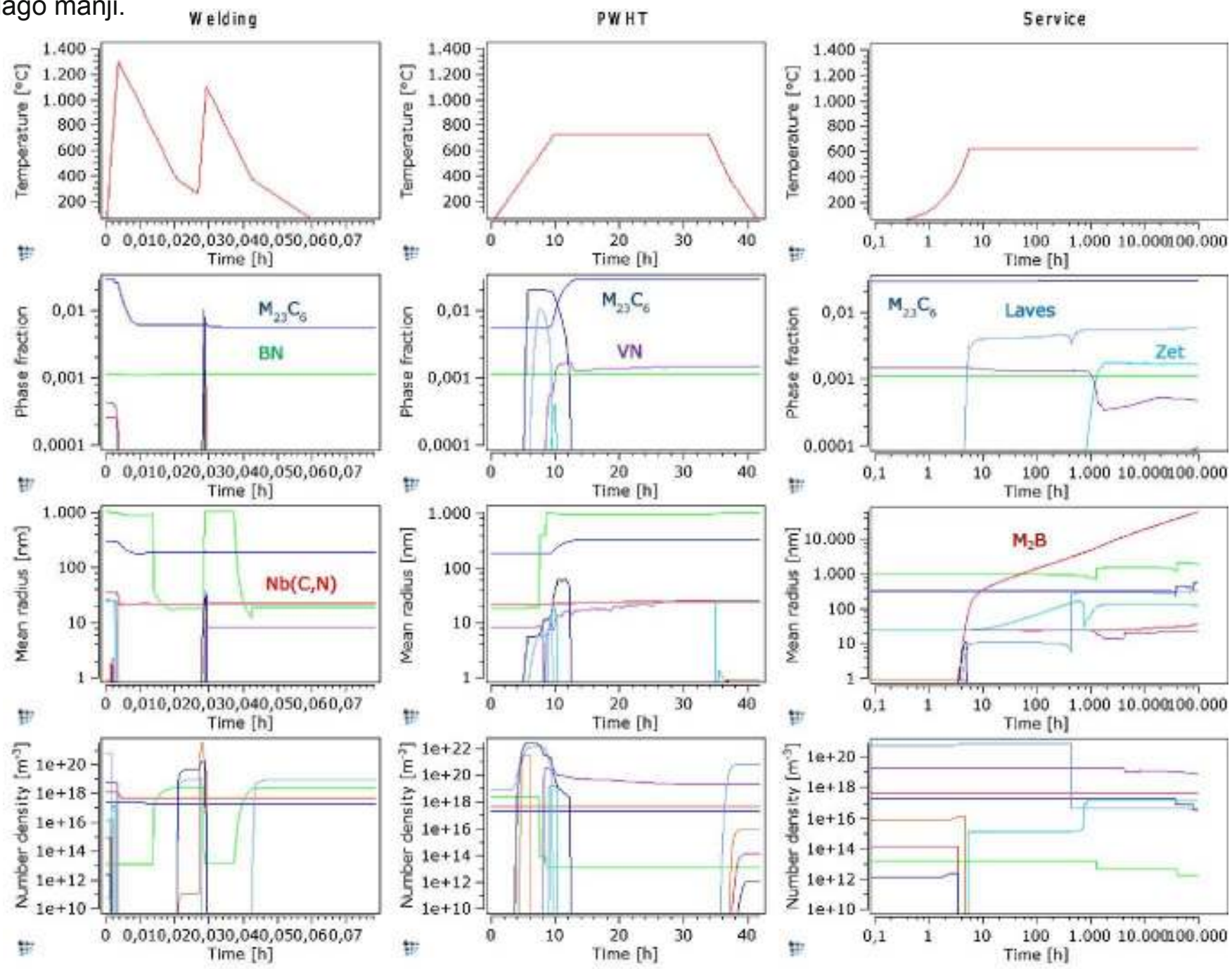

\footnotetext{
- Nb(C,N)(aust) - 8N_HP4(aust) - M23C6 - V(N,C) - M7C3(mart) - laves_phase(mart)

\$: - M2B(mart) - Cem(mart,sgb) - Zet1(mart)
}

Fig. 17 Precipitation evolution in HAZ of CB2 during welding, PWHT, and service

SI. 17. Razvoj taloga u ZUT kod CB2 tokom zavarivanja, TOPZ, i eksploatacije

$\begin{array}{lll} & \mathrm{HAZ} & \text { WM } \\ { }^{\mathrm{M}} 2{ }^{\mathrm{C}} 6 & 583 \mathrm{~nm}, 3.0 \mathrm{wt} . \% & 505 \mathrm{~nm}, 3.0 \mathrm{wt} \% \\ \text { Laves phase } & 335 \mathrm{~nm}, 0.6 \mathrm{wt} . \% & 335 \mathrm{~nm}, 1.0 \mathrm{wt} \% \\ \text { Z-phase } & 138 \mathrm{~nm}, 0.2 \mathrm{wt} \% & 160 \mathrm{~nm}, 0.2 \mathrm{wt} \% \\ \mathrm{BN} & 2,000 \mathrm{~nm}, 0.1 \mathrm{wt} \% & 1,200 \mathrm{~nm}, 0.05 \mathrm{wt} \% \\ \mathrm{NbC} & 36 \mathrm{~nm}, 0.01 \mathrm{wt} \% & 57 \mathrm{~nm}, 0.03 \mathrm{wt} \% \\ \mathrm{VN} & 24 \mathrm{~nm}, 0.05 \mathrm{wt} \% & -\end{array}$

Table 8 Mean radius and phase fraction of precipitates in HAZ and weld metal after service of 100,000 h. Tabela 8. Srednje vrednosti radijusa i udeo faze taloga u ZUT i metalu šava posle servisa na 100.000 sati 
Posle nekoliko sati servisa na $625^{\circ} \mathrm{C}$, javlja se intermetalna Lave faza bez uticaja drugog taloga, ali posle nekoliko hiljada sati, raste udeo Z-faze na račun malih čestica i taložno otvrdnjavajućih $M X$ (VN i NbC) čestica. U pogledu Z-faze, rezultati numeričkog modeliranja treba veoma pažljivo da budu određeni zato što su raspoloživi samo ograničeni termokinetički podaci. Faza $M_{2} B$ pokazuje izuzetan rast radijusa, ali zbog male gustine od samo $1,8 \quad 10^{-2}$ čestica $/ \mathrm{mm}^{3}$, nema značajan uticaj na udele faza drugih taloga.

\subsection{Diskusija rezultata}

Razvoj mikrostrukture u ZUT je drugačiji nego u metalu šava. Pre zavarivanja, već postoje talozi u osnovnom materijalu. Glavni talozi su $\mathrm{M}_{23} \mathrm{C}_{6}, \mathrm{NbC}$, BN i VN, koji se menjaju tokom zavarivanja i TOPZ, ali dostižu sličan nivo posle svake operacije. U metalu šava, $\mathrm{BN}$ i NbC nastaju tokom zavarivanja. Tokom TOPZ, oni ostaju stabilni a talože se $\mathrm{M}_{23} \mathrm{C}_{6}$ karbidi. Glavna razlika je nedostajanje VN u metalu šava. Tokom servisa, javlja se Lave faza i u metalu šava i u ZUT, i Z-faza koja se javlja posle nekoliko hiljada sati servisa konzumiranjem $\mathrm{VN}$ i NbC. U tabeli 8 upoređuju se rezultujući talozi u ZUT i MŠ posle zavarivanja, TOPZ i servisa na $625^{\circ} \mathrm{C}$.

Ovi rezultati simulacije određeni su veoma pažljivo, a mikrostrukturna ispitivanja su poslužila da opravdaju izračunavanja.

\section{Zaključak}

Uticaj parametara zavarivanja na mehaničke osobine na sobnoj temperaturi je ispitivan za svaki metal šava kao i proizvodno ispitivanje sa ciljem razvoja tehnologije zavarivanja sa optimizovanim mehaničkim osobinama. ZUT kao najkritičniji deo zavarenog spoja treba da zadovolji zahteve posebno one, vezane za energiju udara. Najbolji rezultati se mogu postići sa nižom međuslojnom temperaturom, manjom brzinom zavarivanja i manjom brzinom dotura žice.

Prolaskom kroz proceduru kvalifikacije tehnoloije zavarivanja u livnicama voestalpine u Linzu i Traisenu kvalifikovana je punjena žica Böhler CB 2 Ti-FD za koriščenje široke skale $C B 2$ livenih komponenata. Prva ispitivanja puzanjem dokazala su granicu puzanja metala šava i popreko na šav. Do $6.572 \mathrm{~h}$, sve epruvete su se lomile na oko -20 $\%$ rasipanja vrednosti za osnovni materijal.
After few hours of service at $625^{\circ} \mathrm{C}$, the intermetallic Laves phase occurs without influencing the other precipitates, but after several thousand hours, the Z-phase arises in consuming the small and precipitation hardening $\mathrm{MX}(\mathrm{VN}$ and $\mathrm{NbC}$ ) particles. Regarding the Z-phase, the results of numerical modeling have to be evaluated very carefully because there are only limited thermokinetic data available. $\mathrm{M}_{2} \mathrm{~B}$ phase shows an extraordinary radius growth, but due to the low number density of only $1,810^{-2}$ particles $/ \mathrm{mm}^{3}$, it has no noticeable effect on the phase fractions of the other precipitates.

\subsection{Discussion of results}

The microstructure evolution in the HAZ is different to the weld metal. Before welding, there are already precipitates in the base material. The main precipitates are $\mathrm{M}_{23} \mathrm{C}_{6}, \mathrm{NbC}, \mathrm{BN}$, and $\mathrm{VN}$, which change duringwelding and $\mathrm{PWHT}$, but reach a similar level afterwards. In the weld metal, BN and $\mathrm{NbC}$ nucleate during welding. During PWHT, they stay stable and $\mathrm{M}_{23} \mathrm{C}_{6}$ carbides precipitate. The main difference is the missing of $\mathrm{VN}$ in weld metal. During service, Laves phase occurs in both weld metal and HAZ, and Z-phase appears after several thousand hours of service consuming $\mathrm{VN}$ and $\mathrm{NbC}$. Table 8 compares the resulting precipitationsin $\mathrm{HAZ}$ and WM after welding, PWHT, and service at $625^{\circ} \mathrm{C}$.

These results of simulation have to be evaluated very carefully, and microstructural investigations are ongoing to prove the calculations.

\section{Conclusion}

The influence of welding parameters on the mechanical properties at ambient temperature was investigated for all-weld metal and in near production tests to develop a welding technology with optimized mechanical properties. The HAZ seems to be the most critical part of the weld to meet the requirements especially concerning impact energy. Best results could be achieved with lower interpass temperature, lower travel speed, and lower wire feed rate.

Passing the welding procedure qualifications at the voestalpine foundaries at Linz and Traisen qualifies the fluxcored wire Böhler CB 2 Ti-FD to be used for welding of large-scale CB2 cast components. First creep tests prove the creep strength of allweld metal and cross-welds. Up to $6,572 \mathrm{~h}$, all specimens ruptured in the- $20 \%$ scatter band of the base material. 
Prema MatCalc simulacijama, razvoj mikrostrukture u ZUT je različit u odnosu na metal šava. Simulacije su pokazale da se VN i NbC rastvoreni a Z-faza se taloži u ZUT. Ove rezultate treba oceniti detaljnim mikrostrukturnim istraživanjem, na čemu se uveliko radi.

Uticaj hemijskog sastava i parametara zavarivanja na mikrostrukturu i mehaničke osobine nije potpuno proučen u ovom momentu, ali se očekuju mnogo realniji alati za simulaciju koji bi doprineli boljem razumevanju

\section{Reference}

1.Staubli M, Hanus R, Weber T, Mayer K-H, Kern T-U (2006) The European efforts in development of new high temperature casing materialsCOST536, Materials for Advanced Power Engineering 2006, Proceedings of the 8th Liège Conference Part II, Liège, Belgium, pp. 855-870

2. Sonderegger B (2005) Charakterisierung der Substruktur in modernen Kraftwerkswerkstoffen mittels der EBSD Methode, Thesis TU Graz

3.Abe $F$ (2004) Alloy design of creep and oxidation resistant $9 \mathrm{Cr}$ steels for thick section boiler components operating at $650^{\circ} \mathrm{C}$, Advances in Materials Technology for Fossil Power Plants, Proceedings from the Fourth International Conference, October 25-28, 2004, Hilton Head Island, South Carolina, pp.202-216 ->

4.Abe F, Horiuchi T, Sawada K (2003) Hightemperature annealing for maximization of dissolved boron in creep-resistant martensitic 9Cr steel. Mater Sci Forum 426-432:1393-1398

5.Brauné E, Cerjak H, Caminada St, Jochum C, Mayr P, Pasternak J (2006) Weldability and properties of new creep resistant materials for use in ultra supercritical coal fired power plants, Materials for Advanced Power Engineering 2006, Proceedings of the 8th Liège Conference Part II, Liège, Belgium, pp. 871-891

6. Heuser H, Jochum C, Kreuzer-Zagar D (2010) Development of matching filler metals for welding CB2 and first experience, Materials for Advanced Power Engineering 2010. Proceedings of the 9th Liège Conference, Liège, Belgium, pp. 506-513

7.Baumgartner S, Posch G, Mayr P (2012) Welding advanced mar-tensitic creep resistant steels with Boron containing filler metal. Weld World 56(7/8):2-9
According to MatCalc simulations, the microstructure evolution in HAZ is different to the weld metal. The simulations showed that $\mathrm{VN}$ and $\mathrm{NbC}$ dissolved and Z-phase precipitated in the HAZ. These results have to be evaluated by detailed microstructural investigations, which is work in progress.

The influence of chemical composition and welding parameters on microstructure and mechanical properties is not fully understood at the moment, but more reliable simulation tools are expected to contribute to a better understanding.

\section{Product Data Sheet of Böhler CB 2 Ti-FD, www.voestalpine.com/}

welding/austria/products

9. (1990) SEP 1680, Aufstellung von ZeitTemperatur-Umwandlungsschaubildern für Eisenlegierungen, Stahl-Eisen-Prüfblätter des Vereines Deutscher Eisenhüttenleute. 1680

10. Lochbichler C, Schmidtne-Kelity E, Baumgartner S (2013) Latest developments of cast materials and welding consumables for coal-fired steam turbines components/nickelbase alloy A625 and CB2 steel for the A-USC technology, Proceedings of PowerGen 2013, Vienna, Austria

11. Schuler $M$, Baumgartner $S$, Schnitzer $R$, Enzinger N (2014) Creep investigation of CB2 joints using similar rutile CB2-flux cored wire, Weld World, submitted

12. Kozeschnik E (1997) Thermodynamische Berechnung der Phasengleichgewichte und der Ausscheidungskinetik in metallischen Werkstoffen, Thesis TU Graz

13. (2013) http://matcalc.tuwien.ac.at/ , Vienna

Zahvalnost: Autori žele da zahvale austrijskom "Forschungsförderungsgesellschaft" (FFG) za finansijsku podršku zasnovanu na ugovoru br.831995. 